\title{
PENENTUAN AKTIVITAS ANTIOKSIDAN SECARA IN VITRO DARI EKSTRAK ETANOL PROPOLIS DENGAN METODE DPPH (1,1-DIFENIL-2-PIKRILHIDRAZIL)
}

\author{
Santi Sinala $^{1^{*}, \text { Sisilia Tresia Rosmala Dewi }}{ }^{2}$ \\ 1,2 Jurusan Farmasi Poltekkes Kemenkes Makassar \\ ${ }^{*}$ Koresponden : Santi Sinala, Email : santisinala@poltekkes-mks.ac.id
}

DOI: https://doi.org/10.32382/mf.v15i1.820

\section{ABSTRAK}

Penyakit degeneratif seperti kanker, penuaian dini dan jantung dapat disebabkan oleh adanya radikal bebas. Radikal bebas memiliki satu rantai yang tidak memiliki pasangan electron sehingga sangat reaktif untuk mencari pasangan electron pada sel yang normal. Ikatan ini dapat menganggu sinyal sel sehingga terjadilah kerusakan sel pada sel normal. Radikal bebas dapat ditangkal dengan adanya bahan antioksidan. Melihat kandungan polifenol dan flavonoid pada propolis pada penelitian sebelumnya, maka ditelitilah aktivitas antioksidan dari propolis ini. Penelitian ini bertujuan untuk menentukan besarnya aktivitas ekstrak etanol propolis berdasarkan dari nilai IC $_{50}$ (Inhibition Consentrasi) menggunakan metode DPPH. Ekstrak etanol propolis dibuat dalam konsentrasi $400 \mu \mathrm{g} / \mathrm{ml}, 800 \mu \mathrm{g} / \mathrm{ml}, 1200 \mu \mathrm{g} / \mathrm{ml}, 1400 \mu \mathrm{g} / \mathrm{ml}, 1600 \mu \mathrm{g} / \mathrm{ml}, 1800$ $\mu \mathrm{g} / \mathrm{ml}$ dan $2000 \mu \mathrm{g} / \mathrm{ml}$ sedangkan vitamin $\mathrm{C}$ dibuat dalam konsentrasi $10 \mu \mathrm{g} / \mathrm{ml}, 20 \mu \mathrm{g} / \mathrm{ml}, 30$ $\mu \mathrm{g} / \mathrm{ml}, 40 \mu \mathrm{g} / \mathrm{ml}$, dan $50 \mu \mathrm{g} / \mathrm{ml}$. Masing-masing seri ditambahkan DPPH $40 \mu \mathrm{g} / \mathrm{ml}$ dan diinkubasi selama 30 menit. Sampel diukur pada spektrofotometer UV-Vis pada panjang gelombang $516 \mathrm{~nm}$. Nilai $\mathrm{IC}_{50}$ yang diperoleh adalah $1216.66 \mu \mathrm{g} / \mathrm{ml}$ dan nilai $\mathrm{IC}_{50}$ Vitamin C adalah $13.7658 \mu \mathrm{g} / \mathrm{ml}$. Dari hasil ini menunjukkan bahwa ekstrak etanol propolis termasuk dalam kategori tidak aktif dibandingkan dengan vitamin $\mathrm{C}$.

\section{Kata Kunci : Antioksidan, IC50, Ekstrak Etanol Propolis, DPPH, Vitamin C}

\section{PENDAHULUAN}

Radikal bebas merupakan produk dari hasil metabolisme selular. diproduksi dari sel-sel seperti mitokondria, peroxisome, dan reticulum endoplasma, dimana oksigen dihasilkan sangat banyak. Radikal bebas mengandung satu atau lebih electron yang tidak berpasangan sehingga elekron ini tidak stabil, memiliki rentang bertahan yang pendek dan sangat reaktif. Karena kereaktifan tinggi dari electron ini, radikal bebas dapat merebut electron dari bahan yang memiliki stabilitas yang rendah, kemudian menyerang molekul yang kehilangan elekron dan membentuk rantai reaksi yang kuat sehingga dapat merusak sel yang hidup (Mukherji SM, 2001).

Dengan kereaktifan radikal bebas dalam mengikat electron, maka radikal bebas dapat mengakibatkan banyak kerusakan pada sel sehingga dapat menimbulkan banyak penyakit degenerative diantaranya kanker, penuaan dini, diabetes mellitus, jantung dan lain-lain. Sebenarnya tubuh memiliki system imun yang baik dalam melawan radikal bebas, namun kondisi lingkungan yang tidak sehat dapat membuat system imun di tubuh menjadi kurang tanggap, sehingga diperlukan bahan dari luar tubuh untuk membantu system imun alami tubuh dalam memerangi radikal bebas yang disebut antioksidan agent.

Alam telah menyiapkan bahanbahan yang mengandung zat-zat yang berpotensi sebagai antioksidan agent. Salah satunya adalah propolis. Propolis merupakan bahan resin yang dikumpulkan oleh lebah yang bercampur dengan air liurnya. Propolis digunakan oleh lebah sebagai benteng pertahanan untuk bertahan hidup (Pietta, 2002).

Propolis mengandung banyak metabolit sekunder yang dapat digunakan sebagai antioksidan diantaranya polifenol (flavonoid, asam fenolik dan esternya), terpenoid, asam amino dan steroid (Kumazawa et al., 2004).

Santi Sinala, 2016 telah meneliti total polifenol dan total flavonoid dari propolis yang diambil di kota Makassar, 
dimana ekstrak etanol $70 \%$ propolis tersebut yang diperoleh dengan maserasi bertingkat dengan n-heksan memiliki total Polifenol sebesar $6,64 \%$ dan total flavonoid sebesar $4,69 \%$. Kandungan polifenol ini dapat menghambat enzim spesifik, menstimulasi beberapa hormone dan neurotransmitter, melawan radikal bebas dan mencegah pertumbuhan mikroorganisme (Cao et al, 2004; Sforcin, 2007).

Melihat adanya kandungan polifenol dari propolis di atas, maka akan dilakukan uji dalam menentukan aktivitas antioksidan ekstrak etanol propolis dari Kota Makassar.

Berdasarkan latar belakang di atas maka rumusan masalah adalah bagaimana aktivitas antioksidan dari ekstrak etanol propolis secara in vitro dengan metode DPPH (1,1-Difenil-2-Pikrilhidrazil)?

Tujuan dari penelitian ini adalah menentukan aktivitas antioksidan dari ekstrak etanol propolis.

\section{METODE}

\section{Rancangan dan Lokasi Penelitian}

Penelitian ini adalah penelitian eksperimental menggunakan alat pengukuran yaitu Spektrofotometer UV Vis. Penelitian ini dilakukan pada bulan Juli Agustus 2018 di Laboratorium Kimia Jurusan Farmasi Poltekkes Kemenkes Makassar

\section{Alat dan Bahan \\ Alat-alat yang digunakan adalah seperangkat alat maserasi, timbangan analitik, rotavapor, penangas air, freeze dyer, alat-alat gelas, Spektrofotometer UV- Vis. Bahan-bahan yang digunakan raw propolis, n-heksan, air suling, etanol $70 \%$, etanol 96\%, DPPH dan Vitamin C.}

\section{Penyiapan Sampel}

\section{a. Pengambilan Sampel}

Sampel raw propolis diperoleh dari Fakultas Kehutanan Universitas Hasanuddin pada bulan Juli 2018.

\section{b. Pengolahan Sampel}

Raw propolis dimasukkan ke dalam freezer hingga membeku. Setelah membeku, propolis dipotong kecil-kecil dan diserbukkan, lalu diekstraksi.

\section{c. Ekstraksi}

Propolis yang telah diserbukkan ditimbang sebanyak 100 gram lalu diekstraksi secara maserasi dengan n-heksan sebanyak satu liter selama 1 x 24 jam dengan bantuan magnetik stirer. Proses maserasi diulangi sebanyak tiga kali sehingga diperoleh pelarut n-heksan menjadi bening dan residu bebas lemak. Filtrat lalu diuapkan dengan rotavapor hingga diperoleh ekstrak n-heksan kental kemudian dikeringkan di dalam vakum desikator.

Residu hasil ekstraksi n-heksan dimaserasi dengan etanol $70 \%$ sebanyak $500 \mathrm{ml}$ selama 1 x 24 jam dengan bantuan magnetik stirer. Proses maserasi diulangi sebanyak tiga kali. Filtrat lalu diuapkan dengan rotavapor kemudian dikeringkan di freeze dryer sehingga diperoleh ekstrak kental.

\section{Pengukuran Sampel (Penentuan Nilai}

SPF)

a. Pembuatan Larutan DPPH $40 \mu \mathrm{g} / \mathrm{ml}$ Larutan DPPH $40 \mu \mathrm{g} / \mathrm{ml}$ dibuat dengan menimbang sebanyak $40 \mathrm{mg}$ DPPH dilarutkan dalam etanol $96 \%$ hingga $1000 \mathrm{~mL}$.

b. Pembuatan Kurva Baku

Sebanyak $4 \mathrm{~mL}$ larutan DPPH $40 \mu \mathrm{g} / \mathrm{ml}$ ditambahkan dengan $1 \mathrm{~mL}$ etanol $96 \%$ ke dalam vial, kemudian diukur absorbansinya pada rentang panjang gelombang $400 \mathrm{~nm}-800 \mathrm{~nm}$. Akan diperoleh panjang gelombang maksimum dan nilai absorbansi larutan standar DPPH $40 \mu \mathrm{g} / \mathrm{ml}$.

c. Pembuatan dan Pengukuran Larutan Vitamin C

Ditimbang vitamin $\mathrm{C}$ baku $1000 \mu \mathrm{g} / \mathrm{ml}$ sebanyak $100 \mathrm{mg}$ dan dilarutkan dengan etanol $96 \%$ hingga $100 \mathrm{~mL}$. Dibuat pengenceran larutan Vitamin C dari larutan stock $10 \mu \mathrm{g} / \mathrm{ml}$, $20 \mu \mathrm{g} / \mathrm{ml}, 30 \mu \mathrm{g} / \mathrm{ml}, 40 \mu \mathrm{g} / \mathrm{ml}$, dan 50 $\mu \mathrm{g} / \mathrm{ml}$. Pengenceran ini masing-masing ditambahkan $4 \mathrm{~mL}$ larutan DPPH 40 $\mu \mathrm{g} / \mathrm{ml}$ dalam vial. Larutan diinkubasi selama 30 menit, kemudian diukur absorbansinya pada panjang gelombang maksimum larutan DPPH $40 \mu \mathrm{g} / \mathrm{ml}$. 


\section{d. Pembuatan Larutan Baku}

Dibuat larutan stock 20000 $\mu \mathrm{g} / \mathrm{ml}$ dengan melarutkan $100 \mathrm{mg}$ sampel ekstrak etanol propolis sebanyak $50 \mathrm{ml}$ pada labu ukur $50 \mathrm{ml}$ dengan etanol 96\%. Kemudian dibuat pengenceran konsentrasi sampel 400 $\mu \mathrm{g} / \mathrm{ml}, 800 \mu \mathrm{g} / \mathrm{ml}, 1200 \mu \mathrm{g} / \mathrm{ml}, 1400$ $\mu \mathrm{g} / \mathrm{ml}, 1600 \mu \mathrm{g} / \mathrm{ml}, 1800 \mu \mathrm{g} / \mathrm{ml}$ dan $2000 \mu \mathrm{g} / \mathrm{ml}$. Pengenceran ini masingmasing ditambahkan $4 \mathrm{~mL}$ larutan DPPH $40 \mu \mathrm{g} / \mathrm{ml}$ dalam vial. Larutan diinkubasi selama 30 menit, kemudian diukur absorbansinya pada panjang gelombang maksimum larutan DPPH 40 $\mu \mathrm{g} / \mathrm{ml}$.

\section{Analisis data}

Nilai $\mathrm{IC}_{50}$ diperoleh dengan persamaan regresi linear yang menyatakan antara hubungan konsentrasi ekstrak dengan sebagai sumbu $\mathrm{x}$ dan persen penangkapan radikal sebagai sumbu $\mathrm{y}$.

\section{HASIL}

Dari penelitian ini diperoleh hasil berupa ekstrak yang terdiri dari ekstrak nheksan dan ekstrak etanol. Secara lengkap dapat dilihat pada tabel 1. Berdasarkan penelitian yang telah dilakukan, hasil pengukuran aktivitas antioksidan ekstrak etanol propolis yang diperoleh dapat dilihat pada tabel 2 .

\section{PEMBAHASAN}

Propolis merupakan kumpulan metabolit-metabolit dari lebah, berisikan secret dari lebah, air liur, hasil buangan dan getah-getahan dari pohon. Raw propolis berwarna coklat kehitaman, dengan konsistensi yang keras seperti getah.

Untuk memperoleh ekstrak etanol propolis, raw propolis dipotong kecil kemudian diekstraksi secara bertingkat menggunakan pelarut heksan dan etanol $70 \%$. Maserasi bertingkat dengan pelarut nheksan dan etanol $70 \%$ digunakan dalam mengekstraksi propolis dengan tujuan memisahkan senyawa-senyawa non polar yang akan ditarik oleh pelarut n-heksan seperti lemak-lemak dan getah. Hal ini terlihat pada rendamen yang dihasilkan oleh pelarut $n$-heksan dimana beratnya mencapai 1485,80 gram. Sedangkan pelarut etanol $70 \%$ akan menarik senyawa non polar dan polar karena etanol $70 \%$ merupakan pelarut semipolar. Pada penelitian ini ekstrak etanol yang akan ditentukan nilai SPF nya karena pada penelitian sebelumnya, Santi Sinala telah menentukan kadar total flavonoid dan total polifenol yaitu 4,69\% dan $6,64 \%$

Penelitian ini dilakukan untuk mengetahui potensi ekstrak etanol propolis dalam menangkap senyawa radikal atau kemampuannya sebagai senyawa antioksidan menggunakan metode DPPH. Pengukuran aktivitas antioksidan dengan metode ini berdasarkan pada kemampuan suatu senyawa uji menangkap radikal dan mengurangi intensitas warna radikal DPPH yang diukur oleh spektrofotometer pada panjang gelombang yang telah ditentukan sebelumnya, yaitu $515 \mathrm{~nm}$. Hal ini sesuai yang dikemukakan Molyneux (2004) bahwa panjang gelombang teoritis untuk pengukuran DPPH berkisar antara $515 \mathrm{~nm}-$ $520 \mathrm{~nm}$. DPPH adalah radikal bebas yang stabil dan digunakan untuk mengevaluasi peredaman radikal bebas pada bahan alam. Prinsip reaksi metode ini adalah DPPH akan tereduksi oleh proses donasi hidrogen atau elektron sehingga warnanya akan berubah dari violet ke kuning dengan perubahan intensitas warna yang sebanding dengan jumlah donasi elektron yang diikuti dengan penurunan absorbansi DPPH. (Dris dan Jain, 2004 ).

DPPH merupakan radikal yang cukup stabil. DPPH akan tereduksi oleh proses donasi hidrogen atau elektron dan warnanya akan berubah dari violet ke kuning. Senyawa yang dapat menyebabkan ini dapat dipertimbangkan sebagai antioksidan atau bahkan penangkap radikal. Oleh karena itu, DPPH sangat penting digunakan untuk mengetahui aktivitas penangkapan radikal oleh senyawa polihidroksi aromatik.

Dari Tabel 4.1 dan 4.2 dapat diketahui bahwa semakin tinggi konsentrasi sampel yang digunakan maka aktivitas antioksidan juga semakin besar, ditandai dengan berkurangnya intensitas warna menggambarkan penurunan konsentrasi DPPH yang diberi sampel. Semakin besar aktivitas peredaman radikal DPPH maka konsentrasi DPPH yang masih ada semakin kecil, sehingga nilai absorbansi yang dihasilkan semakin turun. 
Dari Gambar 2, menunjukkan bahwa adanya senyawa yang bersifat sebagai antioksidan seperti flavonoid dan vitamin $\mathrm{C}$ akan menangkap atau mereduksi radikal DPPH. Sebagai gantinya, molekul DPPH akan mendonorkan atom hidrogennya sehingga berubah menjadi difenil pikrilhidrazin yang bersifat non radikal. Sisa molekul DPPH yang masih ada dapat dibaca serapannya oleh spektrofotometer pada panjang gelombang $515 \mathrm{~nm}$ yang ditandai dengan berkurangnya warna ungu dari radikal DPPH menjadi warna kuning pucat yaitu warna golongan pikril (Molyneux, 2004).

Parameter yang digunakan untuk aktivitas antioksidan dengan metode penangkapan radikal DPPH ini adalah $I C_{50}$. $I C_{50}$ yakni konsentrasi senyawa uji yang dapat meredam radikal bebas sebanyak $50 \%$. Semakin kecil nilai $I C_{50}$ maka aktivitas peredaman radikal bebas semakin tinggi. Nilai $I C_{50}$ diperoleh dari suatu persamaan regresi linier yang menyatakan hubungan antara konsentrasi senyawa uji dengan persen aktivitas antioksidan.

Setelah diperoleh pengukuran persen inhibisi maka dibuat persamaan regresi linear pada aplikasi pengolah data Microsoft exel. Koefisen y pada persamaan linear bernilai 50 merupakan koefisien $I C_{50}$, sedangkan koefisien $\mathrm{x}$ pada persamaan ini merupakan konsentrasi fraksi, dimana $\mathrm{x}$ yang diperoleh merupakan besar konsentrasi yang dibutuhkan untuk meredam aktivitas radikal DPPH.

Berdasarkan hasil perhitungan $I C_{50}$ menunjukkan bahwa ekstrak etanol propolis memiliki aktivitas antioksidan 1216,66 ppm dan vitamin $C$ sebesar 13,76 ppm. Menurut (Jun dkk, 2003), nilai $\left(I C_{50}<50\right.$ ppm) menunjukkan kekuatan antioksidan sangat aktif, nilai (IC $\left.C_{50} 50-100 \mathrm{ppm}\right)$ aktif, nilai $\left(I C_{50} 100-250 \mathrm{ppm}\right)$ sedang, nilai $\left(I C_{50} 250\right.$ $500 \mathrm{ppm})$ lemah, dan nilai $\left(I C_{50}>500 \mathrm{ppm}\right)$ menunjukkan kekuatan antioksidan tidak aktif. Berdasarkan nilai $I C_{50}$ yang dihasilkan maka ekstrak etanol propolis termasuk dalam kategori tidak aktif $\left(I_{50} \quad 1216,66\right.$ ppm) sedangkan aktivitas antioksidan vitamin $\mathrm{C}$ termasuk dalam kategori sangat aktif $\left(I C_{50} 13,76 \mathrm{ppm}\right)$.

Hal ini menunjukkan bahwa ekstrak etanol propolis tidak aktif sebagai antioksidan. Kurangnya aktivitas antioksidan yang terukur dapat disebabkan oleh kemungkinan rusaknya senyawa yang bersifat antioksidan selama proses pemanasan sehingga tidak dapat menghambat radikal bebas DPPH secara optimal seiring dengan bertambahnya waktu pemanasan. Pada penelitian ini pemanasan dilakukan untuk mengeringkan ekstrak kental yang diperoleh dari proses fraksinasi. Oleh sebab itu diharapkan kepada peneliti selanjutnya agar menghindari pemanasan sehingga dapat meningkatkan potensi aktivitas antioksidan pada sampel yang diuji.

\section{KESIMPULAN}

Dari hasil penelitian dapat disimpulkan bahwa ekstrak etanol propolis memiliki nilai $\mathrm{IC}_{50}$ sebesar $1216.66 \mu \mathrm{g} / \mathrm{ml}$ sehingga termasuk kategori tidak aktif sebagai antioksidan dibandingkan dengan vitamin $\mathrm{C}$.

\section{SARAN}

Dari hasil penelitian ini disarankan untuk penelitian selanjutnya dilakukan pengujian dengan menggunakan pelarut jenis lain.

\section{DAFTAR PUSTAKA}

Apriandi, A.,2011, Aktivitas Antioksidan dan Komponen Bioaktif Keong Ipong-Ipong (Fasciolariasalmo), skripsi, (Bogor : Institut Pertanian Bogor) hlm.18

Cao, Y.H., Wang, Y., \& Yuan, Q, 2004, Analysis of Flavonoids and Phenolic Acid in Propolis by Capillaryty Electrophoresis, Chromatographia, 59, 135-140

Dewi, R.,2012, Aktivitas Antioksidan dan Sitotoksisitas Metabolit Sekunder Daun Salam (Syzygium polyanthum Wight) Dan Daun Jati Belanda (Guazuma ulmifolia Lamk.), Skripsi, (Bogor : Program studi strata satu Institut Pertanian Bogor, 2012), hlm. 4

Frindryani, L.F., 2016, Isolasi dan Uji Aktivitas Antioksidan Senyawa dalam Ekstrak Etanol Temu Kunci (Boesenbergia pandurata) dengan Metode DPPH, S1 Thesis, Fak. MIPA UNY 
Gebara. E.C.E., Lima. L.A. dan Mayer. M.P.A. $2002 . \quad$ Propolis antimicrobial activity against periodontopathic bacteria. J. Microbiol. vol. 33 no. 4 .

Hill. R. 2000. Propolis The Natural Antibiotic.

www.Arkson.com/resources/ipropo lis. Htm.

Kumazawa, S., Hamasaka, T \& Nakayama, T (2004), Antioxidant Activity of Propolis of Various Geographic Orgins. Food Chemistry, 84, 329339.

http://dx.doi.org/10.1016/S03088146(03)00216-4

Lofty M. 2006. Biological activity of Bee Propolis in Health and Disease. Asian Pacific Journal of Cancer Prevention. Vol 7

Mukherji SM, Singh SP, 1986, Reaction mechanism in organic chemistry. Madras : Macmillan India Press).

Muchtadi, D., 2013, Antioksidan dan Kiat Sehat di Usia Produktif, Alfabeta, Bandung

Molyneux,P.,2004 The use of the stable free radical diphenylpicrylhydrazyl (DPPH) for estimating antioxidant activity, Songklanakarin J. Sci. Technol, (Vol. 26 No. 2 Mar.Apr.), hlm. 212
Pietta, P.G., Gardana, C., \& Pietta, A.M, 2002, Analytical Methods for Quality Control of Propolis, Fitoterapia, 73, S7-S20. http://dx.doi.org/10.1016/S0367326X(02)00186-7

Rahman M., Richardson A and Sofian. 2010. Antibacterial activity of propolis and honey against Staphylococcus aureus and Escherichia coli. Academic Journals. Canada

Sinala, S, 2016, Penentuan Total Polifenol dan Total Flavonoid dari Ekstrak Etanol Propolis, Media Farmasi Edisi November 2016, Makassar

Sforcin, J.M. 2007, Propolis and The Immune System : review. Joural of Ethnopharmacology, 113, 1-14. PMid:17580109.http://dx.doi.or/10. 1016/j.jep.2007.05.012.

Triyem, 2010, Aktivitas Antioksidan dari Kulit Batang Manggis Hutan (Garcinia cf. bancana Miq), tesis, (Jakarta: Universitas Indonesia, 2010), hlm.21

Toprakci. M.B.S. 2005. Propolis. http.//www.beehivebotanicals.com/ propolis-nrg-info.html.

Winarsi, H., 2007, Antioksidan Alami dan Radikal, Kanisius, Jakarta 
Tabel 1. Nilai rendamen dari ekstrak

\begin{tabular}{ccc}
\hline Ekstrak & Berat $(\mathrm{g})$ & Rendamen $(\%)$ \\
\hline n- heksan & $145,80 \mathrm{~g}$ & $48,6 \%$ \\
etanol $70 \%$ & $45,06 \mathrm{~g}$ & $15,02 \%$ \\
\hline
\end{tabular}

Tabel 2. Hasil uji aktivitas antioksidan berdasarkan persentase peredaman dan $I C_{50}$ ekstrak

\begin{tabular}{|c|c|c|c|c|}
\hline Replikasi & Konsentrasi & $\%$ Peredaman & $I C_{50}$ & Rata-rata $I C_{50}$ \\
\hline \multirow{7}{*}{ I } & $400 \mathrm{ppm}$ & $17.2977 \%$ & \multirow{7}{*}{$1230.55 \mathrm{ppm}$} & \multirow{21}{*}{$1216.66 \mathrm{ppm}$} \\
\hline & 800 ppm & $34.6123 \%$ & & \\
\hline & $1200 \mathrm{ppm}$ & $53.5534 \%$ & & \\
\hline & $1400 \mathrm{ppm}$ & $57.3570 \%$ & & \\
\hline & $1600 \mathrm{ppm}$ & $63.1856 \%$ & & \\
\hline & 1800 ppm & $70.0336 \%$ & & \\
\hline & $2000 \mathrm{ppm}$ & $75.4132 \%$ & & \\
\hline \multirow{7}{*}{ II } & $400 \mathrm{ppm}$ & $17.4991 \%$ & \multirow{7}{*}{$1204.57 \mathrm{ppm}$} & \\
\hline & 800 ppm & $34.5943 \%$ & & \\
\hline & $1200 \mathrm{ppm}$ & $51.1721 \%$ & & \\
\hline & $1400 \mathrm{ppm}$ & $59.9317 \%$ & & \\
\hline & $1600 \mathrm{ppm}$ & $66.6069 \%$ & & \\
\hline & $1800 \mathrm{ppm}$ & $71.8074 \%$ & & \\
\hline & $2000 \mathrm{ppm}$ & $77.0534 \%$ & & \\
\hline \multirow{7}{*}{ III } & $400 \mathrm{ppm}$ & $17.3909 \%$ & \multirow{7}{*}{1214.88 ppm } & \\
\hline & 800 ppm & $34.6250 \%$ & & \\
\hline & $1200 \mathrm{ppm}$ & $53.5375 \%$ & & \\
\hline & 1400 ppm & $57.1666 \%$ & & \\
\hline & $1600 \mathrm{ppm}$ & $64.1525 \%$ & & \\
\hline & $1800 \mathrm{ppm}$ & $72.1573 \%$ & & \\
\hline & 2000 ppm & $76.9039 \%$ & & \\
\hline
\end{tabular}

Sumber : Data primer 2018

Tabel 3. Hasil uji aktivitas antioksidan berdasarkan persentase peredaman dan $I C_{50}$ Vitamin $\mathrm{C}$

\begin{tabular}{ccc}
\hline Konsentrasi & $\%$ peredaman & $\mathrm{IC}_{50}$ \\
\hline $5 \mathrm{ppm}$ & $25,5049 \%$ & \\
$10 \mathrm{ppm}$ & $38,6815 \%$ & $13.7658 \mathrm{ppm}$ \\
$15 \mathrm{ppm}$ & $52,6405 \%$ & \\
$20 \mathrm{ppm}$ & $68,6500 \%$ & \\
\hline
\end{tabular}

Sumber : Data primer 2018 